\title{
LEGAL ISSUES FOR ELECTRONIC DOCUMENTS WORKFLOW REGULATION
}

Submitted: 10/01/2019

Revised: $26 / 02 / 2019$

Accepted: $27 / 02 / 2020$

\author{
Ainur K. Kussainova* \\ Duman O. Kussainov** \\ Bolat S. Zhumagulov*** \\ Zhomart K. Simtikov**** \\ Baurzhan O. Zhangutin ${ }^{* * * * *}$
}

\begin{abstract}
Purpose - The main purpose of the paper is to analyze the problems of legal regulation of relations in the field of electronic document management.
\end{abstract}

*Doctoral student at the Department of Civil Law and Civil Procedure, Labor Law, AlFarabi Kazakh National University. Research Theme: "Civil Law Regulation of Relations in the Field of Electronic Document Management". His research interests are civil law, business law, contract law, family law. E-mail: kussainova75@yandex.ua. Address: 050040, 71 Al-Farabi Ave., Almaty, Republic of Kazakhstan.

**Associate Professor of the Department of Theory and History of State and Law, AlFarabi Kazakh National University. In 2005, he defended his dissertation on the topic: "Interaction of Branches of Government in the Process of Ensuring the Rights and Freedoms of Citizens in the Republic of Kazakhstan". His research interests are administrative law, constitutional law, the theory of state and law, and ensuring human rights and freedoms. He is the author of more than 100 scientific works, among which there are monographs, study guides, textbooks, and scientific articles.

${ }^{* * *}$ Associate Professor, Institute of History and Law of the Abai Kazakh National Pedagogical University. In 2002, he defended her thesis for the degree of candidate of legal sciences on the topic: "Civil Law Problems of the Institute of Trade Secret in the Republic of Kazakhstan". His research interests are civil law, intellectual law, contract law, business law. Housing law, family law. He is the author of more than 150 scientific works, among which there are monographs, study guides, textbooks, and scientific articles.

${ }^{* * * * *}$ Institute of History and Law, Abai Kazakh National Pedagogical University. In 2010, he defended his thesis on "Constitutional and Legal Framework for Limiting the Rights and Freedoms of Man and Citizen in the Republic of Kazakhstan". He is the author of more than 30 scientific works, among which there are monographs, study guides, textbooks, and scientific articles.

${ }^{* * * * * *}$ Institute of History and Law, Abai Kazakh National Pedagogical University. The sphere of his scientific interests is the Theory of the State and Law, Constitutional and Administrative Law, Human Rights. He is the author of more than 30 scientific works, 4 textbooks in Kazakh languages, over 10 articles in foreign publications. In 2016, he was awarded with the title of "Honorary Worker of Education of the Republic of Kazakhstan”. 
Methodology/approach/design - The paper employs methods of comparative law and analytical, which determine the possibility of integrating international standards for the regulation of electronic document flow.

Findings - Electronic document flow is becoming an integral part of the most diverse areas of economic activity of any enterprise. The document flow contains elements of the general law of regulation and reaffirms the necessity of following specific instructions. Its electronic form allows the information interchange between subjects of economical and legal activity. This defines the possibility of the formation of a separate branch of legal regulation in the document flow. The possibility of the structuring and correlation of an informational and another branch of the law for the aim of complex usage of an electronic document flow is viewed as a separate aspect.

Practical implications - Material of the article may be useful in matters of regulation of the legislative system of document management.

Originality/value - The novelty of the study is that the article examined in detail the mechanism of electronic document management in different countries.

Keywords: Electronic Document. Digital Signatures. CIS Countries. Federal Government. Informational Technologies.

\section{INTRODUCTION}

The modern stage of development of telecommunication and informational technologies contributes to the formation of a new type of records management - management of electronic documents (Fisher \& Harindranath, 2004). We are on the view that the electronic technologies and electronic document flow concerning the modern records management are necessary to view as a united problem (Ab et al., 2018). Due to this, common among them is legal regulation (Duff et al., 1994).

We will point out that, several years ago, for the regulation of the electronic document flow between its users, the preliminary contracts were made about the procedure of the document flow and procedures of the conflicts' solutions, the physical keys and certificates interchange took place (Batura, 2016). However, nowadays economics requires the implementation of the legislative significant electronic document flow more effective, without any previous negotiations between parties (Kindt, 2013a; Kindt 2013b). It is possible to implement with the presence of not only developed and international infrastructure but also developed a normative legal base (Stasis \& Demiri, 2017).

Even though there are practically no fundamental differences in the provisions of legislation regarding the electronic document system and other information systems of various countries, there are still certain nuances that are explained by differences in legal systems (Stasis \& Demiri, 2017). 


\section{LITERATURE REVIEW}

The advantage of the electronic document flow system has no doubt; it allows to optimize the technological processes of the governmental bodies and enterprises of different forms of property (Rüßmann, 2012). In general, in the worldwide practice, a situation has arisen, according to which the electronic document flow regulates the civil and legislative aspects, implementing this in the interests of the electronic business development (Inchausti, 2012). However, new tasks, which has the document flow in the sphere of public law and governmental management, requires its special law regulation (Lawton \& McGuire, 2003). Legislative regulation of electronic document flow is a rapidly developing field, which is taking clearer shape in the modern world (Amann et al., 2012). The national normative database depends on the experience of the electronic document flow of other countries (Jia, 2012). Lawmaking experience of other countries is especially useful when the tendencies of the electronic document flow development correlate with the direction of the countries development, the experience of which is used (Rudzajs \& Buksa, 2011).

All the countries, in which the document flow is regulated, may be divided into 3 blocks (The STCW Convention and related instruments, 2008). Each block has its model inherent in the regulation of electronic document flow (Dumortier \&Verhenneman, 2013). The first block is represented by the postSoviet model of electronic document flow (Mäntysaari, 2010), used in most CIS countries (Commonwealth of Independent States). The second block is the American model of electronic document flow, which is used in the USA, Canada, and other countries. The third block is the European model, which is used in CIS countries.

\section{MATERIALS AND METHODS}

The paper employs methods of comparative law, which determine the possibility of integrating international standards for the regulation of electronic document flow. The analytical method is used to predict the implementation of elements of foreign legal regulation in national legislation systems. For this study, it is extremely important to mention the general (philosophical) method, which determines not only the totality of the specific methods required for this study but also consolidates the scientist's worldview position. There is a special group of interindustrial (interdisciplinary) methods that has arisen and is mainly used in one science, but can be involved in research in other sciences. First of 
all, these are mathematical, statistical, cybernetic, sociological, and psychological methods. The possibility of their application in jurisprudence is justified by the assimilation of the scientific achievements of the technical, natural, and related social sciences by the theory of law (and the state). In the literature on the regulation of electronic document flow, including civil law, the use of such methods should be substantiated in detail, and the rules for their application are to be taken from the relevant sciences. Special methods of other branches of science (statistics, mathematics, cybernetics, psychology) allow us to study only particular connections of legal phenomena, they are not fit for any research.

The study also employs the implementation method, since in many states document flow is based on tradition. In this regard, the presentation of various forms of documents in different countries can be defined as qualitatively different forms of implementation of the legal environment.

\section{RESULTS AND DISCUSSION}

\section{Regulation of Electronic Documents Flow in post-Soviet Countries}

In the first block, the CIS-countries are included, which have similar laws and statutory instruments in the sphere of electronic document flow regulation.

It is necessary to point out that, from the beginning of the 21 st century to the present times, many CIS countries have laws in force that provide for a detailed and deep legal regulation of relations in this field (for example, the Russian Federation, the Republic of Moldova, the Republic of Belarus, the Kyrgyz Republic). In several republics, there are two independent regulations: the Law on the Electronic Document and the Law on the Electronic Digital Signature (for example, the Republic of Tajikistan). In some republics, there is a regulation governing relations in the field of electronic documents and electronic document flow (Ukraine).

Adopted for the first time (on the territory of the CIS countries) on January 10, 2000, in the Republic of Belarus, the Law "On Electronic Document" (currently invalid) defined the concept of electronic documents as "information recorded on a computer medium and meeting the requirements established by this Law".

Subsequently, this Law became invalid in connection with the adoption of the new Law of the Republic of Belarus of 28.12.2009 No113-3 "On electronic document and electronic digital signature", according to which the electronic document is defined as an electronic document with details that allow establishing its integrity and authenticity (Law of the Republic of Belarus ..., 2009). 
On December 19, 2000, the President of Turkmenistan signed the Law of the Republic of Turkmenistan, according to which an electronic document means "information recorded on a computer medium certified by an electronic digital signature following the procedure for creating such a signature" (Law of the Republic of Turkmenistan ..., 2000).

In Russia, the relevant law was adopted on January 10, 2002, No. 1-FZ "On Electronic Digital Signature" (currently invalid). Under Art. 3 of this Law, an electronic document is a document in which information is presented in an electronic and digital form. The main distinguishing feature from other documents is the form of presentation of the document. In the legal literature, many began to note that this definition is too broad, and it does not fully reveal the concept in question, which gives the ground for its ambiguous interpretation when solving problems of legal regulation of the use of electronic documents.

In the Republic of Kazakhstan, the law regulating relations in the field of electronic document flow was adopted on January 7, 2003 - the Law of the Republic of Kazakhstan "On electronic document and electronic digital signature" (Law of the Republic of Kazakhstan ..., 2003). The definition of the electronic document fixed in this Law is more specific: it is a document in which the information is presented in electronic digital form and certified employing an electronic digital signature.

In Ukraine, the Law "On Electronic Documents and Electronic Document Flow" was adopted on May 22, 2003 (Law of Ukraine "On Electronic Documents ..., 2003). Under Article 5 of this Law, an electronic document is a document, the information in which is recorded in the form of electronic data, including the mandatory details of the document. The composition and procedure for the placement of mandatory details for electronic documents are determined by law. An electronic document can be created, transmitted, stored and converted electronically into a visual form. The visual form for submitting an electronic document is a reflection of the data that it contains, in electronic or paper form, in a form convenient for a person to perceive its contents.

On July 15, 2004, the Law of the Republic of Moldova "On Electronic Document and Digital Signature" No. 264-XV (currently invalid) entered into force. The electronic document in it was presented as "information in electronic form, created, structured, processed, stored, transmitted by computer, other electronic devices or software and hardware, signed in accordance with this law by a digital signature".

Subsequently, in the Republic of Moldova, a new Law "On Electronic Signature and Electronic Document" was adopted on May 29, 2014 (2014). The law on electronic signature and electronic document is part of the program for 
integrating the legislation of the Republic of Moldova into the legislative base of the European Union. The preamble of this Law stipulates, "this law provides the necessary basis for the application of Directive 1999/93/EC of the European Parliament and of the Council of 13 December 1999 on the legal framework for the regulation of electronic signatures published in the Official Journal of the European Communities No. L 13 of 19 January 2000”.

Under Article 2 of the Law of the Republic of Moldova, "an electronic document is information in electronic form created, structured, processed, stored and/or transmitted by computer or other electronic devices signed by an electronic signature in accordance with the law".

In 2004, the Legislative Assembly of the Supreme Council of the Kyrgyz Republic adopted the Law "On Electronic Document and Electronic Digital Signature" (currently invalid).

On July 19, 2017, the new Law of the Kyrgyz Republic "On Digital Signature" (2017) was adopted. Under Clause 1, Article 6 of this Law, "Information in electronic form affixed with a qualified electronic signature shall be recognized as an electronic document equivalent to a document in hard copy affixed with a handwritten signature, unless laws or other regulations prohibit the compilation of such a document in electronic form".

In Estonia, judicial institutions, as well as archival and other documents, are involved in the system of electronic document flow. The field of document flow is regulated by the law (Digital Signature Act, 2000; Government Decision..., 2001; Archival Rules, 2011), in which rules and principles are established. Document management and registration are mandatory in the public sector, while the private sector has requirements for particular types of documents - for example, personnel and accounting documents.

The Law on Electronic Communications of the Republic of Lithuania regulates the use of electronic documents in tenders and other procedures that can be carried out based on tenders and other venues (Law of the Republic of Lithuania..., 2004).

Cabinet of Ministers Rules No. 473 of June 28, 2005 (clause No. 33, §§ 5 ) "The procedure for the development, design, storage, and dissemination of electronic documents in state and local authorities and the procedure for the distribution of electronic documents between state and local authorities or between these institutions and individuals and legal entities" is applied in Lithuania. Development and registration, storage and distribution of electronic documents in state and local authorities are carried out following the requirements established in other regulatory acts for the development, execution, storage, and distribution of documents unless otherwise specified in the Rules. If the parties have agreed to sign an electronic document with an electronic 
signature, the requirement for a secure electronic signature and timestamp may be revoked. If the documentary information is not prepared electronically, the authority is not obliged to issue it electronically (unless these provisions specify otherwise) (Rules of the Cabinet of Ministers..., 2005).

The Law "On electronic documents" that are formed based on certain parameters and determines the possibilities for issuing them to citizens and public organizations was additionally adopted (Law of the Republic of Lithuania..., 2003).

\section{Regulation of Electronic Documents Flow in North America}

In the first block, the CIS-countries are included, which have similar laws and statutory instruments in the sphere of electronic document flow regulation. The specificity of this model lies in the traditions of the high level of independence of the territorial constituents (provinces, territories, states) of these countries. The American model simultaneously introduces clear rules for the electronic document flow at the federal level with the presence of various modifications at the level of the federation subjects. The greatest effectiveness and efficiency of this model of regulation of electronic document flow is its use in countries with a large territorial area.

In delving into the study of US experience in the field of legal regulation of electronic document flow, two levels of this regulation should be distinguished. The first level is represented by laws that are developed and adopted in individual states of America, and whose jurisdiction is limited to the states. The second level is the federal. Laws that are adopted at this level extend their jurisdiction throughout the country.

In the United States a situation has developed in which, from the very beginning, lawmaking activity on the regulation of electronic document flow was initiated from the bottom (Sinard, 2006). In just a few years, a nationwide Electronic Signatures in the Global and National Commerce Act was developed and adopted at the federal level. In fact, the Electronic Signatures in the Global and National Commerce Act, adopted by the US Congress in 2000, outlined the concept and legal status of an electronic document. The law equated electronic and paper documents, making it possible to conclude interstate agreements using information technologies without duplicating all the necessary documents in paper form. The law provides that no one should use or accept electronic documents without their consent. For example, if a message is to be sent to the recipient in writing, they will receive it in this form, unless they agree to accept this notice electronically (Seiler, 2005).

Note that although many states adopted independent laws that regulate the use of electronic document flow and electronic signature, the US Congress 
expressed the opinion that it is necessary to have a federal law that would regulate this field since it lacks the unity of opinions and terminology. For example, in some states, it was allowed to use any type of signature (electronic and digital). In other states, electronic signatures were not used, instead only digital signatures operated. There were also states where electronic signatures, according to the law, could only be used in contracts to which the state bodies were a party; other states, without limiting the parties to the contract in using EDS, limited the range of commercial transactions, after which it was possible to use electronic or digital signatures (Obukhov et al., 2019).

Thus, the adoption of the "Electronic Signatures in the Global and National Commerce Act" helped to solve many conflict situations in the field of electronic document flow and electronic commerce that arose between entities registered in different states of America. It should be noted that the adoption of a general law did not abolish legal acts that already functioned in individual states. Over time, they were amended and supplemented, adapting the state laws to the Electronic Signatures in the Global and National Commerce Act (Law on electronic signatures in international..., 2001).

The very first law in the field of electronic document flow appeared in 1995 and was adopted in the State of Utah. Moreover, although the "Utah Digital Signature Act" directly regulated the use of digital signatures in ecommerce, it can be considered the cornerstone in the foundation of legal regulation of electronic document flow in the United States. Although many of the provisions of the Utah Digital Signature Act were vague, confusing, or generally inadequate for the proper resolution of many legal and policy issues in the field of electronic document flow, it provoked interest in this issue not only inside the country but also abroad (Richards, 1999). "Utah Digital Signature Act" became an unofficial model law. On its basis, similar laws on electronic documents and electronic signatures were subsequently passed in states such as Washington, California, Minnesota, Missouri, New Mexico, and Oregon. A common feature for many of these laws is the use of terms such as "message" or "document" instead of the term "electronic document".

In this regard, the Washington Electronic Authentication Act declared the following as the main goals of its operation:

- facilitating trade through reliable electronic messages;

- legal recognition of electronic signatures;

- $\quad$ simplifying the process of conducting commercial documentation by using electronic documents;

- $\quad$ providing a mechanism for licensing certification digital signatures for enterprises, consumers, courts, government agencies, and other entities; 
- establishment of procedures governing the use of digital signatures for the official public business, to ensure confidence in the integrity, authenticity, and reliability of the electronic message;

- minimizing the cases of forgery of digital signatures and electronic documents in electronic commerce; establishment and coordination with the states and other jurisdictions of unified rules regarding the authentication and reliability of electronic messages and the rules for the use of electronic documents.

In the Washington Electronic Authentication Act, the electronic message was equal to the value of a regular document on paper. The e-mail was legal only if it contained a digital signature issued by the confirming center. Thus, the Law noted that the digital signature is an integral requirement of the electronic message. Note that this rule was identical for both the Washington Electronic Authentication Act and the Utah Digital Signature Act (Washington Electronic Authentication Act).

"The California Digital Signature Act", adopted in California, as well as the laws previously reviewed herein, regulated the scope of electronic document flow and digital signature in its state. The specificity of this Law was that it regulated this field only in the public sector, leaving the private sector without attention. Based on the California Digital Signature Act, the California Digital Signature Regulations were developed. The Rules regulated the technology for creating a signature, contained requirements for the creation, operation and licensing of centers authorized to certify signatures. In the California Digital Signature Regulations, instead of the term "electronic document", the definition "message" was used, which meant the digital reproduction of information, which is used as a written document when working with government agencies (Rüßmann, 2012).

It should be noted that the State of Indiana used the experience of the State of California by enacting the Electronic Digital Signature Act in 1997. The law, by analogy with the California Digital Signature Act, established a restriction on the use of digital signatures in the circulation of documents. Digital signatures were only allowed for government agencies, except for the Supreme Court and the Treasury. Audit, legislative, and other legal organizations were also mentioned as an exception.

In 1999, the State of New York adopted the Electronic Signatures and Records Act. This law allowed residents of the State of New York, at their request, to use electronic documents on a par with paper documents. The law explained the term "electronic record", which meant information that recorded any action, agreement, incident, event and other activities stored electronically, 
and which can be presented in the CNC form (Electronic Signatures and Records Act (ESRA), 2017).

Of significance is the law of the State of New Mexico "Electronic Authentication of Documents Act" permitted the use of electronic documents not only in e-commerce but in all areas of activity (Huang and Zhang, 2013). The main objectives of the adoption of the Electronic Authentication of Documents Act are as follows:

- $\quad$ ensuring the creation of a centralized public electronic register for the authentication of electronic documents;

- $\quad$ promoting the development of e-commerce;

- eliminating the barriers resulting from the elimination of legal uncertainties regarding the requirements for electronic signatures;

- promoting the development of legal and business infrastructure necessary for the implementation of secure e-commerce;

- facilitating the exchange of electronic information when submitting documents to public authorities;

- promoting the effective provision of public services by creating reliable, secure electronic records;

- creating approaches to rules and standards regarding the authenticity and integrity of electronic documents that can serve as a model for use by other states.

The "Electronic Authentication of Documents Act" implemented a specific approach to the definition of the essence of an electronic document. Based on the provisions of this law, the electronic document and the paper document were considered not as types of documents, but merely as a form of presentation of information.

Adopted in 1996 in Florida, the "Florida Electronic Signature Act" was similar in its standards to the "Utah Digital Signature Act" (The 2019 Florida Statutes, 2019). The main objectives of the adoption of the "Florida Electronic Signature Act" were:

- recognition of electronic signatures by society and increasing citizens' confidence in the use of electronic documents;

- reduction of fraud related to forgery of electronic signatures;

- $\quad$ promoting the development of e-commerce;

- assistance in the implementation of electronic documents in the activities of state bodies. 
It should be noted that in the "Florida Electronic Signature Act" along with the terms "message" and "document" it is proposed to use the term "writing". "Writing", firstly, means the process of creating an electronic document on any medium with the possibility of submitting it to the $\mathrm{CNC}$ form, and secondly, it involves writing something on paper. Thus, at the state level, a single general term for a paper and electronic document was assigned. The key point of the Florida Act is the provision that an electronic signature is endowed with the same legal force as a handwritten signature and its use for signing documents is permitted.

Within five years of the development and adoption of the Utah Digital Signature Act in Utah, similar laws began to be adopted throughout America. In addition to those already reviewed, the following laws were passed: "Minnesota Electronic Authentication Act" in Minnesota; "Digital Signature Act" in Mississippi; "Digital Signature Act" in Missouri; "Digital Signature Act" in Nebraska; "Electronic Signature Act" in Oregon; "Texas House Bill 984" in the state of Texas, etc.

Investigating the legal regulation of electronic document flow in the United States, one cannot ignore the attempt to create a general law at the federal level for the development of e-commerce. In the United States, in 1999, the National Conference of Delegates for the Unification of State Law adopted the Uniform Electronic Transactions Act (UETA). UETA, in its content, is a model law adopted to provide uniform rules for regulating e-commerce in the United States. UETA applies only to those transactions that the parties agreed to carry out electronically. In fact, the Law did not create a new system of legal norms for the electronic market but only ensured that electronic transactions are equivalent to paper operations and are subject to high-quality execution.

To date, out of 50 states, UETA has been adopted in 46, with some changes, and continues to regulate the scope of electronic document flow (Smedinghoff, 2008). States such as Illinois, New York, and Washington did not accept UETA but developed their laws instead. UETA was one of the first federal laws that not only allowed state government bodies to create, receive and store records electronically, but also declared the need to replace paper workflow electronically, then continued the idea laid down in the Paperwork Reduction Act, adopted in 1995. (Paperwork Reduction Act, 1995)

Paperwork Reduction Act thoroughly regulates the main aspects of the introduction of information technology in public authorities. The provisions of the Act were aimed at:

- maximum reduction of paperwork on citizens, small businesses, educational and non-profit organizations upon concluding agreements 
with the federal government, state authorities, local authorities, and other organizations;

- ensuring the convenience of public information from the federal government;

- improving the quality of federal information systems aimed at increasing the transparency of the federal government;

- reducing federal government spending on collecting, creating, distributing and using information;

- $\quad$ provision of socially significant information promptly, on equal terms and in the most convenient form.

Electronic document flow procedures, compared to the conventional form, are significantly limited and not harmonized.

The "Paperwork Reduction Act" is characterized by the fact that it contains insufficient certainty of the procedures and the determining apparatus of electronic document flow.

According to the provisions of the law, it became clear that the term "electronic format" means electronic documents, but separate explanation of the notion given in the paragraph 3502 Definitions "Paperwork Reduction Act" is not provided.

This gap in the legislation leads to uncertainties in the actions of the subjects of the informational relations, thereby causing the necessity to improve the legislative base.

We shall point out that the great contribution to the improvement of this base was made by the federal organization U.S. National Archives and Records Administration (NARA).

The basic requirements of NARA for working with documents in federal institutions are contained in Chapter 44, "US Code" and in Chapter 36, "Code of Federal Rules".

Provisions stipulated in part 1234 of chapter 36 "Code of Federal Regulations", cover creations, savings, using and placing federal electronic documents, including those which are created with the help of programs of an electronic post.

Strategic plans are adopted as documents defining the focus area of NARA. Currently, the strategic plan for the 2014-2018 financial years is functioning. One of the main directions of the activity of NARA is the realization of the project "Electronic Records Archives". As a basis, it has the creation of the archive system for documents, which allows saving the electronic documents without dependence on the type of digital media and software. 
Within the achievement of the project "Electronic Records Archives", the task to make electronic documents available for the public was also settled (Kiss et al., 2016).

NARA takes an active part in the development and testing of information systems and programs, the preservation of electronic information.

For example, in 1993, NARA specialists took part in the development of document flow management systems for the United States Department of Defense.

Among the standards developed with NARA specialists, it is necessary to mention the DOD Standard 5015.02-STD.

The mentioned standard expanded its scope of work on the military departments of the USA, Joint Chiefs of Staff, Unified Combatant Command, the United States Department of Defense (among which Security Agency and National Reconnaissance Office should be mentioned), structural units of the Security Agency in their places, including in other organizational units that operate within the Department of Defense.

Furthermore, the U.S. National Archives and Records Administration recommends that federal agencies use certified programs that comply with DOD 5015.02-STD to manage electronic records.

In accordance with a 1997 agreement between the US National Archives and Records Administration and the Department of Defense, software developers can provide their software products for testing for a fee following the basic functional requirements of DOD 5015.02-STD.

Successfully tested software products are awarded the Joint Interoperability Test Command (JITC) certificate for two years.

It should be noted that obtaining a certificate indicates not only the high performance of the software product that was tested with NARA but also the importance of the functions that NARA performs.

This is because JITC-certified programs are dual-value products and can be used for both civilian and military purposes.

The experience of Canada is similar to the experience of the USA in the field of electronic document flow regulation.

It should be noted that in Canada, the rules governing the field of electronic document flow, consisting of different laws, are adopted at the federal level and the level of its subjects (provinces and territories).

In 1999, Canada adopted the Unified Electronic Commerce Act (UECA), a model law designed to implement the principles enshrined in the Model Electronic Commerce Act.

Development of UECA took 2 years, after which a functional model for regulating electronic commerce was proposed, based on which provincial and 
territorial authorities can develop their method of regulating electronic commerce.

Aside from the UECA, at the federal level, the Personal Information Protection and Electronic Documents Act (PIPEDA) covered the creation of functional equivalence between electronic and paper documents.

PIPEDA is the main law in the field of electronic document flow, common for all the territories making up Canada.

In PIPEDA, an electronic document is understood as data that is recorded or stored on any digital media, in a computer system or similar device, and can be scanned or perceived by a person, the computer system of another similar device (Obukhov et al., 2018).

Personal Information Protection and Electronic Documents Act regulates the following:

- making federal government payments electronically;

- providing information to the federal government in electronic form;

- use of electronic documents to submit documents to government bodies;

- use of electronic signatures;

- providing electronic documents when the original document is required;

- a distinctive feature of PIPEDA is that it regulates the use of electronic documents as evidence in court proceedings.

In a typical court procedure, the original document is usually necessary to convince the judge that the terms and conditions of the contract have not changed since the signing of the agreement.

To prevent this, PIPEDA requires the identification of electronic documents with the preservation of electronic signatures in cases where the law provides for the use of data in documents as originals.

Over time, the processing of electronic documents in proceedings in Canada has become a separate branch of law with its legislation. The development of electronic communications in Canada led to the adoption in 2008 of many model principles (the Sedona Canada Principles Addressing Electronic Discovery) regulating operations with electronic information that is used in all courts of the country.

The main areas of legal regulation of electronic document flow at the level of provinces and territories of Canada are to clarify the status of electronic documents and contracts concluded in electronic form. 
Northwest Territories, British Columbia, Manitoba and others are following the path of recognition of electronic signatures and documents, building their acts based on the federal Uniform Electronic Commerce Act.

They also contain the rules for electronic document management and related exceptions.

For example, according to the regulations of British Columbia and the Yukon, electronic documents include not only the statements of sworn witnesses but also the constituent documents, documents on the transfer of land, the majority of commissions, etc.

All these documents are either not legally valid if they are in electronic form, or their role in electronic document management is not limited.

However, the laws of some provinces and territories contain rules that distinguish them from the Uniform Electronic Commerce Act.

For example, the Electronic Transactions Act of Alberta (2001) does not provide for legally significant electronic documents containing the right to mines and treasures of the land.

Saskatchewan, in addition to federal law, excludes documents created under the Health Care Directives and Substitute Health Care Decision Makers Regulations from electronic documents flow.

In New Brunswick, the Exclusion Regulation - Electronic Transactions Act is adopted, which states that the federal Uniform Electronic Commerce Act does not apply to areas related to medical services, adoption of children, maintenance of retirement homes, rehabilitation of disabled people, etc.

Each of these areas has adopted its regulation, which also includes rules governing paper flow and electronic document flow.

According to the Exclusion Regulation - Electronic Transactions Act, the following acts were adopted: Family Income Security Act; Family Services Act; Health Services Act; Intercountry Adoption Act; New Brunswick Housing Act; Nursing Homes Act; Vocational Rehabilitation of Disabled Persons Act.

In some provinces, the use of electronic documents has been expanded even more than prescribed by law.

For example, the Electronic Commerce and Information Act (2011) adopted in Manitoba does not contain provisions expressly excluding the electronic document flow for a statement of a sworn witness, power of attorney, land rights and others.

According to the law, it can be concluded that operations with these documents are available in electronic form if they are performed in compliance with the following necessary safety requirements. 


\section{Regulation of Electronic Documents Flow in European Countries}

In the first block, the CIS-countries are included, which have similar laws and statutory instruments in the sphere of electronic document flow regulation. To consider the European model in the field of legal regulation of electronic document flow, it is necessary to indicate the main role of the European Council and the United Nations Commission on International Trade Law (UNICTRAL).

In 1996, UNICTRAL developed and adopted the Model Law on Electronic Commerce.

This e-commerce law has become the standard for developing document flow rules.

The main purpose of this law is to overcome the obstacles that result from differences in the laws of different countries, providing for a different legal regime for paper and electronic information.

To expand the capabilities of electronic documents in the model law, it is recommended to use the so-called "functionally equivalent approach".

The principle of this approach is the transition of a new legal concept (electronic document) to the established legal structures of a convenient "paper" document.

With that, the functions of a paper document for each function are selected equivalently to a functional mechanism from the field of information technology.

In our opinion, the equal treatment of various forms of documents is important to ensure the use of paperless communication, which contributes to the effectiveness of international trade.

In 2001, the Model Law on Electronic Signatures was adopted with this organization (Smedinghoff, 2008). The law aims to create opportunities and facilitate the use of electronic signatures. Its standards expand the possibilities of electronic use of documents.

The Model Law on Electronic Signatures helps European governments in creating a modern, harmonized and fair legal framework, strengthens the legal regime of electronic signatures and document flow upon using them.

After the adoption of both model laws in major European governments, measures were taken in connection with the need to unify the legislation applicable in the field of electronic document flow.

Upon comparing the Model Law on Electronic Commerce and the Model Law on Electronic Signatures, both similar and different features in regulatory approaches can be found. On the one hand, they equally define the concept of electronic signatures, create the same structure of electronic commerce legislation: sender-receiver-certification center.

On the other hand, the directive's approach is more precise and tough. 
The directive defines the rights, obligations and responsibilities of the parties, defines the criteria for confirming electronic signatures, which acquire the character of a continuous list, the emphasis is placed on certification of signatures, although the latter is not mandatory. This leads to unification within the Council of Europe but complicates relations with other states.

In 2000, the European Parliament and the Council adopted Directive 2000/31/EC (Directive 2000/31/EC..., 2000). The Directive pays particular attention to the issues of system building, the use of the services of the information community and obliges the governments of the EU Member States to prevent a technical error upon concluding an agreement using electronic means of communication. After 5 years, Directive 2001/115/EC (2001) governing the electronic processing of invoices with value-added tax was combined with Directive 2006/112/EC (VAT Directive) on a common valueadded tax system (Council Directive 2006/112/EC..., 2006). The preamble is of most interest in the Directive, especially paragraphs 46 and 47 . This is because in these structural parts the VAT directive governs the use of electronic document flow between the EU Member States.

Europe has developed special requirements, standards, programs aimed at working with electronic documents, training in working with electronic documents and the storage of electronic documents.

In 2001, the ERPANET project was launched, aimed at ensuring the preservation of the digital cultural population and digital scientific objects. This year, a unified European specification, Model Requirements for the Management of Electronic Record Specification (MoReq), was prepared. They contain requirements for an electronic document flow system. These specifications have been applied to evaluate the quality of software products used by EU authorities. In addition to implementation in government, MoReq was used as a template for the formation of a set of functions and quality of record management systems in the medical sector, education, industry, etc. Due to the versatility and adaptability of MoReq, they are widely used not only in the EU but throughout the world. Considering the functional effectiveness of MoReq and the development of electronic document flow in 2008, the United European specifications were significantly improved, corrected and published in the new version, MoReq2. In 2002, based on MoReq, the Functional requirements for Electronic Records Management Systems and the Metadata Standard were developed in the United Kingdom.

It should be noted that despite the existence of model laws, many EU countries have their specialized legislation in the field of electronic document flow. 
In 1999, Finland adopted the Act on Electronic Service in the Administration. The decree was adopted for:

- ensuring the security of electronic data transfer using electronic document flow technologies;

- $\quad$ improving the provision of public services;

- regulation of the rights, duties, and responsibilities of state institutions using electronic data exchange technologies.

The peculiarity of the law was that it allows the use of electronic documents with the mutual exchange of data between government bodies and their clients. If this document requires a signature, it must be signed with an electronic signature accepted with a special certificate. This signature may be accepted with foreign certificates if they comply with the rules outlined in the law. Thus, the decree regulated the electronic exchange of data not only between customers (citizens and organizations) and government bodies within the country but also at the interstate level. (Madsen, 1992).

Even though the draft decree was under development for several years, some aspects of electronic data exchange (for example, information security of the judiciary) were left out of the legal framework. In this regard, in 2003, the Act on Electronic Services and Communication in the Public Sector was adopted, which should improve the quality of service delivery, as well as ensure the information security of judicial and other administrative bodies in the field of electronic document flow. The decree also promoted the use of electronic communications in data transmission.

In France, instead of adopting a special law regulating electronic data interchange, a law was adopted that amended the Civil Code. After making changes in 2000, the Civil Code of France gave data in electronic form the same legal force as data on traditional paper media. Then "Décret $n{ }^{\circ} 2001-272 \mathrm{du} 30$ mars 2001 pris pour l'application del'article 1316-4 du code civil et relatif à la signature électronique" was adopted, which regulated the use of digital signatures and brought the legislation of France in line with the European standards.

In Italy, the first steps in terms of electronic document flow regulation were made in 1997. They are associated with the adoption of the Law "Delega al Governo per il conferimento di funzioni e compiti alle regioni ed enti locali, per la reforma della Publica Amministrazione e per la semplificazione amministrativa" and the Decree "Regolamento recante criterie modalita per la formazione, archiviazione e la trasmissione di documenti con strumenti informatici e telematici”. 
The first of these legal acts recognizes any documents created in public or private organizations using computer technology as legal. This provision was also consolidated in the Decree. The decree became a specialized regulation governing the matters associated with electronic documents and digital signatures.

It should also be pointed out that Italy is the only country in the EU that has a "Code of Electronic Government" ("Codice dell'amministrazione Digitale") in the regulatory framework (adopted in 2005, a new version in 2010). Although the Code is aimed at regulating the system of state control, many of its provisions govern electronic documents and stipulate their legal force. For the functioning of the Code, the Italian government developed special regulations, some of which govern certain parts of electronic document flow: the use of electronic invoices, the use of electronic signatures.

It should be noted that the process of creating an integral legal framework has not yet been completed and continues to this day. For example, at the end of 2014, a new technical regulation was adopted on the creation, transfer, copying, replication, reproduction, and establishment of the time for the creation/passage of electronic documents, including the creation and preservation of electronic documents by state bodies ("Regole tecniche in material di sistemadi conservazione ai sensi degli articoli 20, commi 3 e 5-bis, 23-ter, comma 4, 43, commi 1 e 3, 44, 44-bis e 71, comma 1, del Codice dell'amministrazione digitale di cui al decreto legislativo n. 82 del 2005"). However, even with its adoption, some issues (related to computer security and functioning of the State Electronic Identification System) remain open, and some problems of electronic document flow are still unresolved.

On July 1, 2016, the eIDAS (electronic IDentification, Authentication and trust Services) regulations on electronic identification and trusted services began to work in the EU countries (eSignature Documentation, 2016). It came into force after the adoption of Regulation (EU) $\mathrm{N}^{\circ} 910 / 2014$ and the repeal of the eSignature Directive of 1999. The regulation sets a common standard for electronic signatures, electronic stamps, time stamps, eDelivery services, and website authentication certificates. Mandatory mutual recognition of electronic identifiers by EU countries is valid from September 29, 2018.

The main changes in the legislation on electronic signatures after the adoption of eIDAS were:

1. The legal status of law (instead of a directive) makes it directly applicable throughout Europe without the need for inclusion in national legislation. Thus, all European digital signatures are now harmonized and implemented by a unified standard. 
2. The ability to introduce new technical solutions for remote signing. Electronic documents shall not be invalidated for the sole reason that they are in electronic form.

3. The introduction of electronic seals available to legal entities, technically similar to an electronic signature. They ensure the identity and integrity of documents.

4. Introduction of timestamps.

5. Inclusion of national Trusted Lists.

6. Qualified electronic signature verification service.

However, the signatures that are considered qualified following the Russian legislation are not recognized as qualified signatures under the requirements of eIDAS law. It "contains a number of additional requirements (not provided for by Russian legislation, being based on an earlier version of the European Directive), compliance with which allows recognizing an electronic signature as qualified. For example, using a highly secure device to create a signature is mandatory. From the standpoint of European law, Russian qualified signatures are regarded precisely as enhanced electronic signatures based on a qualified certificate".

Due to the adoption of eIDAS, electronic document flow is gradually becoming the standard in the European Union. It is expected that by 2022 electronic and digital signatures will overtake conventional signatures as the main means of signing documents in the EU.

\section{CONCLUSION}

While analyzing the experience of the CIS countries in the field of legal regulation of electronic document flow, it is necessary to highlight that one of the ways to bridge the gap with leading countries is to actively use the accumulated experience, consolidated not only in the laws of such countries but in sub-legislative acts and standards as well. The experience of the CIS countries is of particular interest, mainly because all these republics have started developing the field of electronic document flow under equal conditions, which were characterized by Soviet traditions of records management and the legislative framework of the same type.

Proceeding from the analysis, it can be pointed out that the specificity of the American model of electronic document flow is the presence of model laws regulating the field of electronic document flow, e-commerce, and electronic (digital) signatures. This approach recognizes that the relevant rules governing the use of electronic documents and signatures are critical for the subsequent KussainOVA, A. K.; KUSSAINOV, D. O.; ZHUMAGUlOV, B. S.; SIMTIKOV, Z. K.; ZHANGUTIN, B. O. Legal Issues for Electronic Documents Workflow Regulation. The Law, State and Telecommunications Review, Brasilia, v. 12, no. 1, p. 293-318, May 2020. 
development of a business that is implemented through electronic communications. The government gives the right to e-commerce participants to independently regulate internal processes, based on the principles of "business choice", the concept of freedom of contact, using any technology available. Any action agreed upon between e-commerce participants will be considered legal. Currently, the use of the American model has demonstrated the absence of adverse legal uncertainties in electronic document flow and e-commerce. It should be noted that the rules of electronic document flow according to the American model correspond to the modern level of development of technologies and electronic communications, which allows introducing corrections and amendments to the regulations on time.

In summarizing the consideration of the European model in the field of legal regulation of electronic document flow, it appears expedient to highlight the existence of equal rules regarding electronic document flow, which are consolidated in the regulations of the European Parliament. Nevertheless, the commonalities of approved regulations that are binding with the EU Member States, and interstate features of the legal regulation of electronic document flow are very different. For example, in Italy and Finland, there is an increase of control over electronic documents using electronic signatures; in France, on the contrary, an approach to regulating electronic document flow is rather loose, resulting in the absence of a specific law in this area. In our opinion, the areas of legal regulation of document flow in the EU countries are very similar to the experience of the United States. In Europe, instead of the federal level and federal legislation, the level of supranational structures (the European Union) is introduced, which forms its vision of solving problems related to electronic document flow in the form of developing and adopting directives. Similarly to the US states and provinces and territories Canada, the EU Member States adhere to the general provisions outlined in the directives, individually deciding on the necessity of legislative changes.

\section{REFERENCES}

AB, A. A.; MOHAMMAD, Y. Z.; MOKHTAR, U. A.; JAMBARI, D. I. Electronic Document and Records Management System Implementation in Malaysia: A Preliminary Study of Issues Embracing the Initiative. In G. Chowdhury; J. McLeod; V. Gillet; P. Willett (Eds.), Transforming Digital Worlds. Cham: Springer International Publishing, p. 585-591, 2018. 
AMANN, P.; DILLON, M.P.; QUIRCHMAYR, G. Challenges to Advanced Electronic Evidence Lifecycle Management in an International Court Environment. In B. Papasratorn; N. Charoenkitkarn; K. Lavangnananda; W. Chutimaskul; V. Vanijja (Eds.), Advancesin Information Technology. Berlin, Heidelberg: Springer Berlin Heidelberg, p. 31-45, 2012.

Archival

Rules.

2011.

Retrieved

from:

https://www.riigiteataja.ee/akt/129122011229.

BATURA, O. Liberalisation of Telecommunications Services Markets and Regulation of Universal Service in the European Union. In Universal Service in WTO and EU Law: Liberalisation and Social Regulation in Telecommunications. The Hague: T.M.C. Asser Press, p. 117-214, 2016.

Council Directive 2001/115/EC of amending Directive 77/388/EEC with a View to Simplifying, Modernising and Harmonising the Conditions Laid Down for Invoicing in Respect of Value Added Tax. 2001. Retrieved from: https://eur-lex.europa.eu/legalcontent/EN/ALL/?uri=CELEX\%3A32001L0115

Council Directive 2006/112/EC on the Common System of Value Added Tax. 2006. Retrieved from: https://eur-lex.europa.eu/eli/dir/2006/112/oj

Digital Signature Act. 2000. Retrieved from: https://www.riigiteataja.ee/akt/694375

Directive 2000/31/EC of the European Parliament and of the Council of 8 June 2000 on Certain Legal Aspects of Information Society Services, in Particular Electronic Commerce, in the Internal Market ('Directive on electronic commerce'). 2000. Retrieved from: https://eurlex.europa.eu/legal-content/EN/ALL/?uri=CELEX\%3A32000L0031

DUFF, W.; THOMAS, D.; WALLACE, D. Working Meeting on Electronic Records. Arch Museum Informatics, v. 8, n. 4, p. 301-352, 1994. doi:10.1007/BF02770381.

DUMORTIER, J.; VERHENNEMAN, G. Legal Regulation of Electronic Health Records: A Comparative Analysis of Europe and the US. Heidelberg: Springer Berlin Heidelberg, 2013. doi:10.1007/978-3-64222474-4_2. 
Electronic Signatures and Records Act (ESRA). 2017. Retrieved from: https:/its.ny.gov/sites/default/files/documents/nys-g04-

001_electronic_signatures_and_records_act_ersa_guidelines.pdf

Electronic Transactions Act of Alberta. 2001. Retrieved from: http://www.qp.alberta.ca/documents/Acts/E05P5.pdf

eSignature Documentation. 2016. Retrieved from: https://ec.europa.eu/cefdigital/wiki/display/CEFDIGITAL/What+is+the+ legislation+-+eSignature

FISHER, J.; HARINDRANATH, G. Regulation as a Barrier to Electronic Commerce in Europe: The Case of the European Fund Management Industry. European Journal of Information Systems, v. 13, n. 4, p. 260-272, 2004. doi:10.1057/palgrave.ejis.3000510.

Government Decision “Uniform Principles of Case Law”. 2001. Retrieved from: https://www.riigiteataja.ee/akt/130122011062.

HUANG, L. H.; ZHANG, X. Q. Preliminary Study on Digital Signature Technology and Application. Advanced Materials Research, v. 734, p. 3158-3162, 2013.

INCHAUSTI, F. G. Electronic Service of Documents National and International Aspects. In M. Kengyel; Z. Nemessányi (Eds.) Electronic Technology and Civil Procedure: New Paths to Justice from Around the World. Dordrecht: Springer Netherlands, p. 137-180, 2012. doi:10.1007/978-94-007-4072-3_8.

JIA, L. Modeling Framework for Document Flow in Office Automation System for Colleges and Universities. In J. Luo (Ed.) Affective Computing and Intelligent Interaction. Heidelberg: Springer Berlin Heidelberg, p. 725-732, 2012. doi:10.1007/978-3-642-27866-2_88.

KINDT, E. J. The Criteria for the Correct 'Balancing of Rights'. In Privacy and Data Protection Issues of Biometric Applications: A Comparative Legal Analysis. Dordrecht: Springer Netherlands; 2013a, 631-743. doi:10.1007/978-94-007-7522-0_7.

KINDT, E. J. The Risks Involved upon the Use of Biometric Data and Biometric Systems. In Privacy and Data Protection Issues of Biometric Applications: A Comparative Legal Analysis. Dordrecht: Springer Netherlands, p. 275-401, 2013b. doi:10.1007/978-94-0077522-0_4. 
KISS, P.J.; KISS, J.K.; KLIMKÓ, G. Electronic Document Certification Service: An Enabler of e-Government Uptake in Hungary. In A. Ho; E. Francesconi (Eds.) Electronic Government and the Information Systems Perspective. Cham: Springer International Publishing, p. 276$286,2016$.

Law of the Kyrgyz Republic “On Digital Signature" No. 128. 2017. Retrieved from: http://cbd.minjust.gov.kg/act/view/ru-ru/111635?cl=ru$\mathrm{ru}$

Law of the Republic of Belarus "On Electronic Document and Electronic Digital Signature" No. 113-3. 2009. Retrieved from: http://kodeksyby.com/zakon_rb_ob_elektronnom_dokumente_i_elektronnoj_tsifrovoj _podpisi.htm

Law of the Republic of Kazakhstan "On Electronic Document and Electronic Digital Signature" No. 370-II. 2003. Retrieved from: https://online.zakon.kz/document/?doc_id=1035484

Law of the Republic of Lithuania "On Electronic Communications" No. IX2135. 2004. Retrieved from: https://www.etar.lt/portal/lt/legalAct/6d0095f07c4611e8ae2bfd1913d66d57.

Law of the Republic of Lithuania "On Electronic Documents". 2003. Retrieved from: https://likumi.lv/ta/id/68521-elektronisko-dokumentulikums\&xid=17259,15700019,15700124,\%2015700149,15700168,15700 $186,15700190,15700201 \% 20 \& \% 20 u s g \% 20=\% 20 A L k J r h g y Q k V o 5 D N u$ CEzlf9Qi0A9ajw1wbA.

Law of the Republic of Moldova "On Electronic Signature and Electronic Document" No. 91. 2014. Retrieved from: http://base.spinform.ru/show_doc.fwx/doc_to_word.fwx?rgn=71212

Law of the Republic of Turkmenistan "On Electronic Document". 2000. Retrieved from: http://medialaw.asia/node/176

Law of Ukraine "On Electronic Document and Electronic Document Flow" No. 851-IV. 2003. Retrieved from: http://singlewindow.org/docs/67

Law on Electronic Signatures in International and Domestic Trade Relations. 2001. Retrieved from: https://www.russianlaw.net/law/edoc/esign/a127/ 
LAWTON, T. C.; MCGUIRE, S. M. Governing the Electronic Market Space: Appraising the Apparent Global Consensus on E-Commerce Self-regulation. Wiesbaden: Gabler Verlag; 2003:51-72.

MADSEN, W. International, National and Sub-National Data Protection Laws.

In Handbook of Personal Data Protection. London: Palgrave Macmillan UK, p. 231-1012, 1992. doi:10.1007/978-1-349-12806-8_10.

MÄNTYSAARI, P. Management of Information. Heidelberg: Springer Berlin Heidelberg, p. 335-469, 2010. doi:10.1007/978-3-642-027505_10.

OBUKHOV, A. D., KRASNYANSKIY, M. N., DEDOV, D. L., KARPUSHKIN, S. V. Mathematical Model of Information Processing in Electronic Document Management System. International Review of Automatic Control, v. 11, n. 6, p. 336-345, 2018.

OBUKHOV, A. D.; KRASNYANSKIY, M. N.; DEDOV, D. L. Automation of Structural and Parametric Synthesis of Electronic Document Management Systems Based on Neural Network Architecture. International Review of Automatic Control, v. 12, n. 3, p. 115-122, 2019.

Paperwork Reduction Act. 1995. Retrieved from: https://www.congress.gov/bill/104th-congress/senate-bill/244/text.

RICHARDS, R. J. The Utah Digital Signature Act as "Model" Legislation: A Critical Analysis. The John Marshall Journal of Information Technology \& Privacy Law, v. 17, n. 3, p. 873-908, 1999.

RUDZAJS, P.; BUKSA, I. Business Process and Regulations: Approach to Linkage and Change Management. In J. Grabis; M. Kirikova (Eds.) Perspectives in Business Informatics Research. Heidelberg: Springer Berlin Heidelberg, p. 96-109, 2011.

Rules of the Cabinet of Ministers of Republic of Lithuania No. 473. 2005. Retrieved from: https://likumi.lv/doc.php?id=111613.

RÜßMANN, H. Electronic Documents. Security and Authenticity. In M. Kengyel; Z. Nemessányi (Eds.) Electronic Technology and Civil Procedure: New Paths to Justice from Around the World. Dordrecht: Springer Netherlands, p. 233-260, 2012. doi:10.1007/97894-007-4072-3_12. 
SEILER, J. P. How is Good Laboratory Practice Regulated? In Good Laboratory Practice - the Why and the How. Heidelberg: Springer Berlin Heidelberg, p. 59-358, 2005. doi:10.1007/3-540-28234-3_2.

SINARD, J. External Regulations Pertinent to LIS Management. Practical Pathology Informatics: Demstifying Informatics for the Practicing Anatomic Pathologist. New York: Springer New York, 2006.

SMEDINGHOFF, T. J. The Legal Challenges of Implementing Electronic Transactions Uniform. Commercial Code Law Journal, v. 41, n. 3, p. 32, 2008.

STASIS, A.; DEMIRI, L. Secure Document Exchange in the Greek Public Sector via eDelivery. In S. K. Katsikas; V. Zorkadis (Eds.) EDemocracy -- Privacy-Preserving, Secure, Intelligent EGovernment Services. Cham: Springer International Publishing, p. 213-227, 2017.

The 2019 Florida Statutes. 2019. Retrieved From: http://www.leg.state.fl.us/statutes/index.cfm?app_mode=display_statute \&url=0600-0699/0668/0668.html.

The Electronic Commerce and Information Act. 2011. Retrieved from: https://web2.gov.mb.ca/laws/statutes/ccsm/e055e.php.

The STCW Convention and Related Instruments. In Maritime Work Law Fundamentals: Responsible Shipowners, Reliable Seafarers. Heidelberg: Springer Berlin Heidelberg, p. 422-639, 2008. Retrieved from: https://link.springer.com/chapter/10.1007/978-3-540-72751-4_4

Washington Electronic Authentication Act. Retrieved from: https://casetext.com/statute/revised-code-of-washington/title-19business-regulations-miscellaneous/chapter-1934-washington-electronicauthentication-act. 